\title{
The contested nature of coastal climate change - commentary to Niven and Bardsley. Planned retreat as a management response to coastal risk: a case study from the Fleurieu Peninsula, South Australia
}

\section{Ralf Buckley}

\section{Introduction}

Human responses to anthropogenic climate change are highly contested. Historical evidence from other threats to health and nature indicates that the social responses are politicized. Different groups argue for different responses, based on their own perceived risks and opportunities. They use political techniques, including manipulation of information (Beder 1997). The politicization of scientific information is well known in some fields, such as disease, defence and development (Flyvberg et al. 2012). This is the origin of political ecology. Historically, research on physical processes such as sediment erosion (Buckley 1987) or sea level change (Willis and Church 2012) was not politicized; but now it is (Anderson and Bows 2012; Phillips 2012).

The recent analysis by Niven and Bardsley (2012) of sea level rise at Fleurieu Peninsula in South Australia (N\&B) includes a case study from Byron Bay, Australia. N\&B rely largely on materials produced by Byron Shire Council, BSC. These, however, are highly politicized sources of information, because BSC is the main protagonist in an intense legal and political contest. The history and politics of the Byron Bay case have been outlined by Buckley (2008). The legal issues at Byron Bay have been outlined independently by McDonald (2007a) and summarized cogently by Coleman (2011), representing Byron residents. The broader legal issues for coastal climate change in Australia have been detailed by McDonald (2007b, 2010, 2011) and a key legal antecedent by Coleman (2010).

I argue here that N\&B have inadvertently perpetuated the perspectives propounded by BSC, which are politically motivated and factually incorrect. My comments refer only to the N\&B case study of Byron Bay, not Fleurieu Peninsula. They are an alert for academics in politicized debates (Buckley 2006). I also propose general principles for researchers involved in contested social responses to coastal climate change worldwide. Similar views have been put forward by Anderson and Bows (2012). 
As in most nations, rise in mean sea level is important for coastal planning in Australia, but not urgent. At timescales of days to decades, surge and surf associated with large lowpressure storm systems are many orders of magnitude more damaging. At these timescales, engineering defences are straightforward, using long-established structures and standards, funded by landowners (Buckley 2007). This is perfectly feasible at Byron Bay (Buckley 2007, 2008). It corresponds to approaches used for threats from, for example, fire, floods or cyclones. At timescales of 50-100 years, when sea level rise will become comparable to storm surge in its significance, human populations and their distribution will have changed markedly, and the world may well be facing thirst, starvation, epidemics and war.

\section{Critique of Byron Bay case study}

Information sources

The N\&B Byron case study is based on information from two main sources. The first is BSC, from 4 sources: an undated BSC document which misrepresents history to promote current policy; a 2010 interview with an unspecified BSC officer, who represents the BSC political position; a conference presentation by BSC representatives (Fitzgibbon and Barham 2008, cited in N\&B); and a draft Coastal Management Plan produced by BSC, which was not adopted because of successful legal challenge by property owners. The second source is the public mass media, including local and national newspapers and television channels (11 citations in $\mathrm{N} \& \mathrm{~B}$ ). Just as industry proponents work to create a dominant media myth in support of the development proposals (Flyvberg et al. 2002), however, BSC has worked to create a media myth in support of its current coastal retreat policy. This is not an accurate information source. Newspaper editorials and letters, and radio and TV interviews can demonstrate the range of stakeholder perspectives (Alexander and Ryan 2012; Alexander et al. 2012) and, in some cases, their geographic distribution (Buckley 2008). They do not, however, provide reliable information on the actual history of legislation, litigation, land use and tenure, erosion and progradation, coastal geomorphology and dynamics, patterns in storm surge or mean sea level, or even the weight of public opinion.

\section{Policy history}

Contrary to claims by BSC, cited by $\mathrm{N} \& \mathrm{~B}$, a policy of retreat has not been in place since 1988. Current BSC members were not in power in 1988, and the views of their predecessors were very different. Indeed, climate change was not part of any public agenda in 1988. Historical records of Council meetings show when the term was introduced and debated. Part 
J of the 1988 Development Control Plan (DCP) restricts what oceanfront landowners can do, but it says nothing about retreat. Were it not for the BSC misinterpretation of DCP Part J, Byron beachfront landowners would long since have repaired and linked the long-established seawalls, improved their designs and revegetated the sand dunes, as is standard practice in other local government areas nearby.

\section{Engineering practicalities}

The BSC policy of retreat, if it were ever to be adopted, is unworkable in practice. Many of the oceanfront properties are fronted by a major seawall built in the 1970s on an adjacent State Government road reserve. The wall is made of large basalt boulders weighing several tons each, and its foundations are far below the current level of the beach and have only been exposed during one storm in the past quarter century. There is no vehicular right of access along the beach, and no other way to get to the wall. It would cost tens or hundreds of millions of dollars to remove that wall, and it is extremely unlikely that the State Government would pay for this. If it did, it would be exposed to immediate and almost certainly successful compensation claims by the oceanfront landowners, since it would undermine the foundations of their own properties. This wall, and the oceanfront properties themselves, protects an entire suburb, road infrastructure, and Byron's largest patch of mangroves and associated birdlife. BSC has never advanced any valid reason for wanting to remove it.

\section{Local legal peculiarities}

Every individual location has its own physical, social, legal and political peculiarities. Byron has many. The 1988 DCP Part J, which has given BSC a mechanism to pursue retreat, exists only at Byron. Beach erosion at Byron has been caused not by climate change or sea level rise, but by an artificial headland and shore-normal groyne in the middle of Byron's urban coastline, built decades ago to protect public property. As noted by $\mathrm{N} \& \mathrm{~B}$, affected residents have recently lodged a large-scale compensation claim. No social, economic or environmental advantages from a retreat policy have been demonstrated (Buckley 2008).

\section{Conditional occupancy}

Contrary to the BSC views quoted by N\&B, landowners who bought Byron oceanfront property did not do so under conditional occupancy rights. The key conditions for these (Alexander et al. 2012) are as follows: advice before purchase; no prior construction; appropriate design; and inclusion in conveyancing contracts. None apply at Byron. BSC 
prevents residents from protecting private properties at their own expense and even from maintaining protection built four decades ago. At the same time, it proposes to extend structures protecting public land, creating further damage to private land.

Economics and equity

Contrary to claims by various protagonists at Byron (Buckley 2008; N\&B), there is no ratepayer subsidy of oceanfront properties. In fact, the reverse is the case. Because rates are based on rateable land value, it is the oceanfront landowners who subsidize all the services provided in the hinterland. Indeed, the rates paid by the Byron oceanfront landowners alone, since this dispute began, could have funded an entire sand-pumping system to shape Byron's beaches as local residents may desire, in the same way as on the Gold Coast slightly to the north (Buckley 2008).

\section{Recent politics}

Whilst NSW State legislation, as noted by N\&B, has moved to address coastal management in a more integrated manner, this has not yet happened at Byron Bay. Instead, BSC tried to introduce a retreat policy through a Coastal Management Plan. This was defeated by a local residents association, because it failed to follow State Government requirements.

On 6 June 2012, an extraordinary meeting of BSC voted to exhibit a new draft Local Environmental Plan (LEP), which included retreat provisions, contrary to state-wide frameworks. The Minutes show that Council staff brought the meeting a modified version of the draft LEP, intended to steer between the conflicting requirements of the Councillors and the State Government, and that the Councillors decided that their staff could exhibit the modified version. A week earlier, however, the General Manager of the Council staff resigned, with no reasons given (Anon 2012).

In September 2012, local government elections were held throughout NSW. BSC now has a different mayor, albeit still one affiliated with the Byron Shire Green political faction. It has 2 Councillors from the same faction, 4 from two groups which stood for election on prodevelopment platforms and 2 who stood on local community-oriented platforms. Perhaps, this new BSC will be able to adopt a more rational response to urban coastal management. In October 2012, the draft LEP was exhibited for public comment, but with contentious coastal areas deferred. In addition, the NSW Government passed the Coastal Protection Amendment 
Bill, which allows for various temporary coastal protection works. Outcomes remain to be seen.

\section{Conclusions}

People defend themselves strongly against attempts to destroy their hard-earned lifetime assets. There are long-established legal systems for compulsory purchase of private land, but BSC is trying to force residents off their properties without compensation, through longrunning legal manoeuvring. Resistance by residents was predicted long since and should not be surprising to any experienced policymaker. Nowhere else will have quite the same quirks as Byron, but everywhere has its own history of land tenure and local politics.

Buckley $(2007,2008)$ proposed three general principles for social responses to coastal sea level rise, and these are all applicable very broadly. First, risks to coastal built environment from storms and floods are currently much greater than from rising mean sea level. Second, the best response to sea level rise over the next few decades is to enhance engineering protection along existing built coastline, but to halt development on currently undeveloped low-lying rural coastlines. Third, funding is feasible by making individual landowners, public or private, responsible for protection works on their own properties, following pre-approved and hence coordinated engineering designs. Legal aspects to these are reviewed by McDonald (2007a, b, 2010, 2011).

Responding to climate change is a political as well as a technical process, and academics must be aware that they may become political tools. As noted in a different context (Buckley 2012), "Whilst academics see information as having intrinsic value and incorruptible importance, most of the world sees information mainly as a means to gain power, fame or money. The products of research become tools of advocates, politicians and entrepreneurs, no matter how hard researchers strive to remain independent. This is particularly prevalent in contested domains".

I thus propose three general principles, which are relevant to regional environmental change worldwide. Firstly, everywhere has its own local peculiarities. Secondly, in highly politicized public debates, information is unreliable. Thirdly, researchers may themselves be used, unwittingly, as political tools. 


\section{References}

Alexander K, Ryan A (2012) Using social functionalist frameworks to understand responses to projected sea level rise and managed retreat policies in Australia. Int J Climate Change: Impacts and Responses 3:127-138

Alexander KS, Ryan A, Measham TG (2012) Managed retreat of coastal communities: understanding responses to projected sea level rise. J Environ Plan Man 55:409-433

Anderson K, Bows A (2012) A new paradigm for climate change. Nat Climate Change 2:639-640

Anon (2012) Byron GM resigns in surprise move. Byron Shire News 31.05.2012, p 8

Beder S (1997) Global Spin. Scribe, Melbourne

Buckley RC (1987) The effect of sparse vegetation on the transport of dune sand by wind. Nature 325:426-428

Buckley RC (2006) Industry: speak up to stop its pressure on academia. Nature 440:868

Buckley RC (2007) Climate response. Griffith University, Brisbane

Buckley RC (2008) Misperceptions of climate change damage coastal tourism: case study of Byron Bay, Australia. Tour Rev Int 12:71-88

Buckley RC (2012) Sustainable tourism: research and reality. Ann Tour Res 39:528-546

Coleman K (2010) Coastal protection and climate change. Aust Law J 84:421-422

Coleman K (2011). Barriers to effective climate change adaptation. Submission 120 to Australian Productivity Commission inquiry into coastal climate change. King \& Wood Mallesons for Byron preservation association. Accessed 18 Sep 2012 at: http://www.pc.gov.au/_data/assets/pdf_file/0007/117484/subdr120.pdf 
Flyvberg B, Holm MS, Buhl S (2002) Underestimating costs in public works projects: error or lie? J Am Plan Assoc 68:279-295

Flyvberg B, Landman T, Schram S (2012) Real social science. Cambridge UP, Cambridge

McDonald J (2007a) The adaptation imperative: managing the legal risks of climate change impacts. In: Bonyhady T, Christoff P (eds) Climate law in Australia. Federation Press, Sydney, pp 124-142

McDonald J (2007b) A risky climate for decision-making: the liability of development authorities for climate change impacts. Environ Plan Law J 24:405-417

McDonald J (2010) Mapping the legal landscape of climate change adaptation. In: Bonyhady T, McIntosh A, McDonald J (eds) Adaptation to climate change: law and policy. Federation Press, Sydney, pp 1-37

McDonald J (2011) The role of law in climate change adaptation. Wiley Interdisc Rev Clim Change 2:283-295. doi:10.1002/wcc.96

Niven RJ, Bardsley DK (2012) Planned retreat as a management response to coastal risk: a case study from the Fleurieu Peninsula, South Australia. Reg Environ Change. doi:10.1007/s10113-012-0315-4

Phillips L (2012) Sea versus senators. Nature 486:450

Willis JK, Church JA (2012) Regional sea-level projection. Science 336:550 